\title{
A plea for the honour of God: Gisbertus Voetius' mission proposals at the National Synod of Dordrecht and his mission theory
}

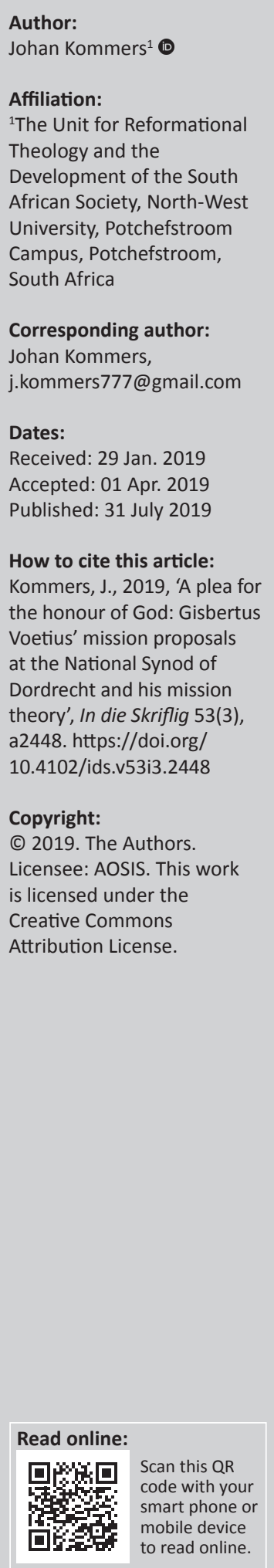

This article searches for the dynamic in human terms that produced today's global church. It will focus on the role and the vision of Gisbertus Voetius (1589-1676), the father of the Reformed science of missions. As a significant representative of early modern Reformed theology, Voetius set his seal on the mission paragraph in the decisions of the National Synod of Dordrecht, held in 1618-1619 in one of the oldest cities in the then young republic of the Netherlands. In addition is the far-reaching influence of his mission principles in Reformed missions. The focus in this study is on Voetius' missiology which, as we will see, is that, in the whole discipline of his theology and mission ideas, the honour of God was his highest aim.

Keywords: Ecclesiastical mission; Mission; Missionaries; Pietism; Reformation; Reformed; Confessions; Reformed theology; Synod of Dordrecht.

\section{Praxis pietatis}

Since the second decade of the 17th century, Voetius became a significant representative of early modern Reformed theology and a central figure, national and international, in the Reformed Protestantism of the 17th century. His inaugural speech, De pietate cum scientia conjungenda in 1634 as professor at the newly founded University in Utrecht, set the tone for his future academic program. In a time of upcoming Cartesianism, he gave a passionate wake-up call to the students to devote themselves to their studies in true piety in order to be in the academic research subservient to the honour of God and the salvation of men.

Already at a very young age, he went into that direction when, in 1604, he got a study bursary at the then well-known international recognised university in Leyden - an institution famous for its classic studies. In Leyden, he followed the conflict between the professors, namely Arminius and Gomarus.

As student, as a pastor and finally as theological professor, he followed Gomarus: 'I never have had another position than being on Gomarus side and never have disputed against him. [...] Till the end of my life I will be his thankful student' (Van Asselt 2007:14, [author's translation]). He was a ferocious reader and, as a real scholar, he often rose at four o'clock in the morning to study Semitic languages. In 1636, he received his doctorate in theology at the university in Groningen with Gomaris being his promotor. In his typical Victorian style, the Utrecht professor in practical theology, J.J. van Oosterzee (1817-1882) said about Voetius: ‘He was a pupil of Gomarus, and, like his master, he assumed the attitude of an ecclesiastical Hercules, cleansing the Arminian Augean stable' (Van Oosterzee 1883:2464). ${ }^{1}$ The wealth of Voetius' knowledge in all his books brought Christiaan Sepp (1820-1890), pastor in the Mennonite Church, to the conclusion that it is 'almost limitless' (Beeke 1999:33). In 1677, the auction catalogue of his library contains more than 4777 theological titles and miscellanea (Van Asselt 2007:15).

In 1611, Voetius was ordained as pastor in Vlijmen (1611-1617), followed by a pastorate in Heusden (1617-1634). His remonstrant colleague in Heusden prevented him to come to the town. Since then, his conflict with the Remonstrants and their doctrines were a constant factor in his further life. Voetius saw that the continuance of the Reformed faith was constant at stake by the remonstrant opposition. During his 17 years of pastorship in Heusden, he was already discussing the Roman Catholic views about the apostolic succession and the mission activities of that church. In 1612, he married Deliana van Diest with whom he had 10 children. His preaching, eight times 
a week in his congregation or outside, brought many Roman Catholics into the Reformed church. He also persuaded the far-reaching trading companies to carry missionaries on their ships. In 1634, we meet him as professor at the new founded Utrecht University - soon to be called the Academia Voetiana.

Today Voetius is seen as one of the most prominent figures of a movement who, in time, became famous for its practical piety known as the Nadere Reformatie (in England: the puritan pietism; in Germany: der Pietismus). Belonging to the intellectual elite of his time, he sought for the heart of the people. By his practical theological views in his collected university lectures Disputationes Theologicae Selectae (1648-1669) and in Te Askètika sive Exercitia pietatis (1664) as well as at his sermons, he exerted a tremendous influence on churchgoers and students. For him, theology was a theologia ascetica, a theology of 'menigvuldige aandoeningen en gewaarwordingen, behoeften en verschijnselen, alle betrekking hebbende op een vroom, Gode gewijd bestaan'. This made him 'een van die mees sentrale figure in die Nadere Reformasie' (Hofmeyr 1989:27).

As a prolific and fluent writer, he was interested in all the upcoming theological issues of his time. In an age where the seafaring countries discovered the world, people from far away and from other religions became known. Voetius saw that the Christian church had a responsibility towards non-Christian countries and on that, we now turn to focus on his mission views and involvement. He absolutely believed in the unique meaning of God's revelation in Christ and based his mission vision on the Bible and, with a respectful heart, the vestiges of God's presence in the world of religions.

Voetius considered the Christian faith as the only true religion. Only through belief in Christ, one can be saved, and immediately he (Voetius 1659:12) adds, 'that is, within the Christian church'. In his confrontation with the Remonstrants, we see Voetius as a real defender of the Reformed faith. In the Voor-Reden of his Catechisatie over den Catechismus der Remonstranten, he argued that the claim of the Remonstrants to be Reformed is pure deceptive. The Remonstrants are not Reformed, but they are 'Remonstrant, Socinian Christians' (Voetius 1659:4).

\section{Early mission voices}

For centuries, Europe had laid under medieval spiritual darkness. Christians in name, the vast majority, had been deprived of the gospel. However, the seed of mission effort was sown long before Voetius was born. Around 1400, John Wycliffe's 'poor preachers' were missionaries to England and lowland Scotland. The followers of John Huss (1372-1415) and Jerome of Prague (1370-1416) performed the same work in central Europe and often paying the price with their blood. These preachers saw their work in missionary terms.
In the Renaissance period, following the Middle Ages and characterised by revived interest in Classical learning and values, age-old manuscripts of the Bible, among other things, were studied by Erasmus (1466-1536) which helped Bible translators tremendously. When Reformers such as Luther, Melanchthon, Zwingli, Farel, Calvin and others appeared on the scene, gospel preaching went out to the nations of Europe with increased vigour.

Erasmus, in his Ecclesiastes sive de ratione concionandi (1535), gave a stirring appeal not to lose sight for the conversion of the non-Christian people. Already in 1501, he had expounded his ideas in his Enchiridion (cf. Welzig1968, I:X-XI). He disagreed with public authorities and the popes in Rome who attacked and even killed people (e.g. the Turks) to expand their own territory and power, but not the kingdom of God. ${ }^{2}$ About the Bible, Erasmus wrote: 'The Scripture has to be translated in every tongue' (Wiersinga 1959:30). Gustav Warneck (1900:9) honours Erasmus as the man who 'eine beredne Apologie der Missionspflicht und ein kräftiger Missionsaufruf an die Zeitgenossen richtte'. Van den Bosch (1932-1933:496) saw Erasmus as the 'erste Stimme' [first voice] to enjoy an increasing public profile for mission in the dawn of the Reformation.

The descendants of the Reformation in the Reformed church in the young Dutch republic were convinced of the possibility and necessity of Christian missionary outreach in the non-Western world. Guido de Brès (1522-1567), the author of the Belgic Confession, never went overseas; yet, he regarded his work as missionary work. He saw many people, including Roman Catholics, as living in darkness. His Confession may be considered as a missionary witness to the world of his time. We honour Adrianus Saravia (1530-1613) who, as pioneer, saw that not the government, but the church has the mission mandate. He did not implicate Matthew 28 on the apostles only, but saw it as the task of the church hinc et nun as explained in 1561 in his De diversis ministrorum Evangelii gradibus (Bakhuizen van den Brink 1960, I:269).

\section{A Reformed voice}

In Martin Bucer (1491-1551) 'is een groot zendingsman verloren gegaan' (Van de Linde 1976a:203). Bucer, the Protestant religious Reformer and mediator, looked for more than the Reformation in Strasbourg. He longed for a gospel preaching to the most remote place in the world and that the most dark 'frömbde Völcker' [strange people] should hear it:

Der Herre wölle unseren Fürsten und Obren verstandt und willen verleyen, die Christenheit warlich $\mathrm{zu}$ erweitern und zubesseren. Nicht nachlassen an alle mensen, 'auch Juden, und Turcken und allen unglaubigen, zu denen sie ein zugang jmer haben mögen, uff dass sie alle die, so unter solchen Christo angehören, zu Christo auch gentzlich bringen. (Van den Bosch 1932-1933:558, 561)

2.'Et ut feliciter cadat Martis semper ancipitis ales, fiet, ut latius fortasse regnet pontifex aud huius cardinales, non ut latius regnet Christus.' 
One has to recognise that the Genevan Reformer, Calvin, and other leading Reformers saw the object of mission in broader terms than many of us do today. For them, Europe under the sway of Roman Catholicism was essential pagan or, at least, sub-Christian. The Reformers made no distinction between local evangelism and foreign mission. For them the lost were close at home as well as in distant overseas countries. In 1544, a delegation was sent from the fledging Reformed church in Tournai (then located in the Netherlands; today located in Belgium) to Geneva, requesting that they should send a Reformed missionary because of the great paganism in the country. This brought Klooster (1972:187) to the conclusion that the Reformation 'deserves to be called one of the greatest home missionary projects in all history'. Gospel outreach was seen as mission - whether local or otherwise; whether within a culture or cross-cultural.

Voetius, known with the Calvinistic teachings, knew that Calvin always insisted that the church has an abiding call to bring the gospel to the nations. Scholl has shown that, in Calvin's extant congregational prayers, one can hear Calvin praying for the gospel to go out to those who are lost. We see 'eine ausgesprochene Verkündigungs- und Missionsterminologie' (Scholl 1968:155-156). For Scholl, Europe, under the sway of Roman Catholicism, was a pagan continent or at least subChristian. In his Institutions, Calvin, explaining the Lord's Prayer, sees God being praised and honoured from all over the world. The 'brothers in Christ' are yet known and not yet known. 'En niet alleen hen, die Hij tegenwoordig ziet en kent als zodanig, maar alle mensen die op de aarde leven' (Calvijn n.d. 2.3:440). God is willing that all poor ignorant people (tous les pauvres ignorants) on this earth will know him. 'Wij moeten wensen, dat dit dagelijks geschiede, opdat God zich kerken verzamele uit alle streken van de wereld, die in getal uitbreidde en vermeerdere, met Zijn gaven verrijke' (Calvijn n.d. 2.3:441, 445). For Calvin to be Reformed was in the given circumstances missional (Dankbaar 1978:191).

In Lutheranism, the missionary calling of the church remained a theme for theological discussion. Reformed churches embarked on missionary action (Gensichen 1971:18-19). While mission emphasis was present within the first Reformed generations, it grew stronger with the coming generations, especially among the adherents of the Reformed pietism - in the Netherlands called the Nadere Reformatie [Further Reformation] and in England, the Puritanism. In Reformed confessions, mission work was mentioned, as the Scots Confession of 1560 evidenced missionary awareness when it bore the words of Christ in Matthew 24:14: 'And the glad tidings of the Kingdom shall be preached through the whole world for a witness to all nations, and then the end shall come.' Actively, the northern part of Scotland was evangelised around the middle of the 16th century (Mackichan 1927:64-65).

In the young Dutch republic, we see in the Dutch Reformed church of the 17th century a strong emphasis to be in an active way involved in mission work. Mission theory, highlighted at the Synod of Dordrecht, was translated in practice in present-day Indonesia, Taiwan, Sri Lanka, Brazil and the north-eastern part of the United States, and later also in South Africa. The one who came with a detailed theology of mission is the study object, Gisbertus Voetius. The arrangement with the government and actual situation were often less than ideal. It all reflected an ongoing missionary consciousness among Reformed believers in the 17th century. Practically, because the Netherlands and England now became maritime powers, the whole world became more in the focus, for now they could control the sea routes (cf. Neill 1982:220-221). We have to acknowledge that the first 'fathers' of the Reformed church on missiological terms did not come into action, but among all these mission minded persons and efforts, Gisbertus Voetius was the 'einflugreichste reformierte Theologe der Niederlande im 17. Jahrhundert' (Galm 1915:56). Seen as the first protestant composer of a systematic missiology (Jongeneel 1991:47), Voetius did not work in a mission vacuum.

In 1602, we see the launch of the Verenigde Oost-Indische Compagnie (VOC) and in 1621, the West-Indische Compagnie (WEC). Both companies were to stimulate and to be actively involved in business with the overseas colonies. Lay clergymen were sent with the ships to the East and the West to promote the Christian religion among the immigrants and partly to serve their personnel with the gospel. In1622, the VOC supported the foundation of the Seminarium Indicum of the theologian Waleus (1573-1639), but this institution already closed in 1632. More than once, Voetius raised his critical voice regarding the work of the VOC, for it is not surprising that business was more promoted than religion. They often prevented pastors in doing their work on the mission field. It was the VOC who prevented the inhabitants of Ternate and Japan to become Christians - and when they entered in business contracts with infidels, it was, in Voetius opinion, harmful for the mission. He also saw the danger of explosive growth of the Roman Catholic mission (Pol 1910:58).

\section{Voetius and the Mission issues at the National of Dordrecht}

Voetius' hard work during his pastorate in Heusden preaching mostly eight times a week and a busy pastorate and academic studies - earned him an appointment to the international Synod of Dordrecht (1618-1619) where he played a prominent role.

As a delegate of the regional Synod of South Holland, Voetius attended as the youngest participant the National Synod (Biografisch lexicon voor de geschiedenis van het Nederlandse Protestantisme - BLGNP 1978-2006, II:443-449). Indissolubly, he set his stamp on the National Synod, mainly called together to sort out the conflict $^{3}$ between Gomaris and Arminius. In his vision for the church, Voetius was strongly focused to be exclusive Reformed, and at that time, it meant Calvinistic. Upcoming puritan and pietistic church leaders in the Netherlands saw in Voetius, with his scholastic theology 3.With this conflict will be dealt in another article in this edition. 
and pietistic piety, their defender. On the other side stood the delegates who joined Arminius and later also Coccejus with his covenant theology - a mix of pietistic piety, but with more rationalistic tendencies (cf. Van den Berg 1978:9).

The Synod of Dordrecht has been the first National Synod that purposely dealt with mission issues (cf. Kaajan 1914:352-368). At the Synod, Voetius, a strong advocate of foreign missions, was involved in the evaluation of the mission paragraph brought in a gravamen by the two regional Synods (Noord-Holland and Zeeland): 'Van de voortbereydinghe des Evangeliums in Oost-Indien, ende andere plaetsen die van ons pleghen besocht te worden'4 [Of the preparations to bring the gospel to East India and other places we use to visit] (Van Andel 1912:16, [author's translation]).

During the Synod, the question of the extent of the atonement was raised. The Arminians stated in the second of their five articles that Christ had died for each and every person so that he obtained the atonement and remission of sins for all. They made the difference between sufficienter and efficienter. For them, the atonement did not have a personal character, but a general and indirect one. The efficiency of the atonement was made dependent upon the belief of a person. According to the Arminians, between the atonement in Christ and the actual fact of having received the atonement, lay the appropriation by belief (cf. Bakhuizen van de Brink 1960, I:277-280). Those on Gomarus' side protested, as for them the reality of the atonement is volkomen [real] and cannot made dependent of a condition that has to become a reality from human side (cf. Bakhuizen van den Brink 1960:287-288). It is not surprising that Voetius, as an adept of Gomaris, stressed the necessity of preaching to the people, and urged in his De Plantatione et Plantatoribus Ecclesiarum (in Voetius 1663-1676) for a complete surrender and conversion. To enter the kingdom of God was also a necessity for the people outside the Christian world.

It were the Canons of Dordrecht that, at the very beginning, have an introduction with a truly evangelical heart. To the people, lost in debt and sin, preachers were sent to tell them the glorious gospel. It is a short and a powerful indication of the missio Dei (cf. Bosch 2001 [1991]:389-393). As Krüger (2007:562) concludes: 'From the Canons of Dordrecht we now know that the end is also guaranteed: all those who have been intended for eternal life, will inherit it.' In Dordrecht, Voetius defended the Reformed concept that, in the Dutch republic and on the mission field, there will be no moral constraint (coactio conscientiae), but freedom of conscience (libertas conscientiae). However, this freedom is not freedom to propagate and to defend publicly in word and deed as false religion, for the Reformed government has 'te weren en uit te roeien alle valse afgoderij en valse Godsdienst, en het rijk van de Antichrist te vernietigen' (art. 36 of the Confessio Belgica).

4.Öld Dutch.

\section{Some gravamina}

At the Synod, discussions were held about the practice by which conversion of the heathen might be advanced, about the practice of the baptism of children of the heathens and the use of the Malay language in East India (Joosse 1992:323). In one gravamen, submitted by the classis of Amsterdam, the following question is put to the synod: 'Whereas ... in the East Indies ... the matters of Religion and the Worship of God are running into great disorder, it is asked what should be done to improve these things?' (Kuyper 1899:437). Another gravamen from the classis Amsterdam requested, 'That matters be put in order for the Ministry of the Word and the spread of the Gospel in East India' (Kuyper 1899:468). From Zeeland came a similar request, 'That matters be put in order for the conversion of the Heathens' (Kuyper 1899:443).

We see that the language of these requests submitted to the national Synod evidences a lively missionary concern in the churches of the Dutch republic. The first gravamen from Amsterdam suggests at least a pragmatic interest in the sorting out of the issues facing the church overseas, while the other two are indisputably missionary in their intent, desiring 'the conversion of the Heathens' and 'the Ministry of the Word and the spread of the Gospel in East India'. These mission matters were brought to the table of the National Synod, but from there the Synod also drafted a petition on the matter that they submitted to the StatesGeneral. This petition, recorded in the Acts of the Synod, was as follows:

Aende Hooch Mogende Heeren de Heeren STATEN GENERAEL vande Vrije Vereenichde Nederlanden, onse gebiedende Heeren $[. .].[H]$ et SYNODUS NATIONAEL der Gereformeerde kercken ... heeft gelet, so op de Leere ende Ordre deser kercken in't gemeyn, als op verscheydene gravamina int bysonder van de kercken deser Provincien tot dese vergaderinge Synodael ingebracht $[\ldots]$ Ende nademael alle ware Christenen, door de Liefde, die sy behooren te dragen tot de verbreydinge van Gods eere onder de menschen, ende tot de salicheyt van hare naesten, verplicht zijn alle middelen aen te wenden daartoe dienstigh, ende de Heere dese Landen den wech geoopent heeft tot verscheydene Landen inde Indien ende elders, die van de ware ende salichmakende kennisse Godts ontblootet zijn, so is meer des Synodi ootmoedigh versoeck, dat uwe Hooch Mog. gelieve met Christelycken ernst ende yver dese saecke te behertighen, ende tot dien eynde te beramen, ende by der handt te nemen alsulcke middlen, als tot voortplantinge des h. Euangeliums in deselve Landen dienstigh ende allerbequaemst sullen wesen. ${ }^{5}$ [To their Excellency's the Lords of the States-General of the Free United Netherlands, our rightful rulers [...]. The National Synod of the Reformed churches [...] has given attention to the Doctrine and Order of these churches in general, as well as to various gravamina in particular that were submitted to this synodical gathering by the churches of these Provinces [...]. And whereas all true Christians, through the Love which they ought to bear for the spread of God's glory among mankind, and for the salvation of their neighbours, are obliged to use every means for this end, and [whereas] the Lords of these lands have opened up the way to various Lands in the Indies and elsewhere,

5.In 17 th century Dutch. 
which are destitute of the true and saving knowledge of God, therefore it is the Synod's humble petition, that their Excellency's might be pleased, with Christian seriousness and zeal, to tend to these matters, devise plans, and take in hand every means as shall be serviceable and most apt for achieving the goal of the propagation of the holy Gospel in these Lands]. (Kuyper 1899:261-262, 267)

From the Zeeland Synod came the proposal to ask the government to provide means to bring the Jews to belief in Christ. The National Synod decided in a positive way. In addition, a mission paragraph was discussed with the delegates from England, Germany and Switzerland about baptism of the heathen ${ }^{6}$ children in East India. Voetius was actively involved in the deliberations on this subject and wrote the text of advice to the provincial deputies (cf. Van Andel 1912:16, 175-182).

In these above-mentioned examples, we see that the National Synod of Dordrecht, in its function as the general assembly of the Reformed churches in the Netherlands, involved itself in a significant way in seeking to advance both the discussion of mission issues within the republic and its churches as well as the practical effect of this missionary push originating in the churches.

That this was a serious issue in the church in the young republic can be seen in the number of ministers sent to the East Indies. Before 1620, there were only nine ministers and in the years direct after the Synod, there were 24 ministers, and by 1640 , there were hundreds if we include also the ziekentroosters. These last were lay people who had some instruction to help the sick. The East India Company renewed its charter in 1622 and, in the same year, also established a seminary specifically for the training of missionaries under Antonius Walaeus in Leiden - probably the first of its kind. All this demonstrates that the Reformed church in the Netherlands, 50 years after its upcoming in the first national synod, to be self-consciously busy with the issues of missions (cf. Niemeijer 1996:32, 199).

However, for Voetius this Synod was a traumatic experience. In the confrontation with the Remonstrants, Voetius with his scholastic minded theology was afraid that many members of the Synod were inclined to adapt themselves in the thinking of the Remonstrants with their accent on feeling, and who had a milder opinion of their heresies (cf. Van de Linde 1976b:130). For Voetius, the foundation of our salvation is not to define in 'ethic' or in 'moral', but pneumatic and therefore a paradox (peccator - iustus-sanctus). In his Praxis pietatis and his Vita spiritualis, he tries to connect in a dogmatic scholastic thought with mystic elements (Van de Linde 1976b:163). Deeply involved in battling the Arminians, he suffered from the deep gap between the true Reformed and the others. Not only the breach between the Lutheran and Calvinistic Reformed tradition, but, as he saw it, also the heresies of the Arminians encouraged him to defend the most plain and true Reformed church, namely the Calvinistic of normal usage. one in the best possible way. The Calvinists held the opinion that their religion was magis certa et infalibilis than that of the others. Voetius spent most of his time and energy to defend the official church orthodox doctrine of the Reformed church against all old and new errors.

In his disputation addressed to the Socinians about the trinity of God, he writes: 'Wij zullen, zolang adem in ons is, blijven strijden' [We will continue to fight as long as breath is in us] (Voetius 1641:55, [author's translation]). Concerning several practical areas, Voetius was also disappointed with the results of the Synod, especially the government's influence on the Synod. It were the Articles of Dordrecht that form the basis of his extensive book of four volumes, the Politica Ecclesiastica (1663-1676). In this book, he also worked out some of his ideas about mission and the planting of the church. Unfortunately, the journal he kept during the Synod has been lost (Beeke 1999:11).

\section{Voetius' contextual mission concept}

As mentioned before, Voetius revealed his mission heart to his first two congregations, Vlijmen and Heusden. He has been influential in persuading various trading companies to take missionaries with their ships to distant parts of the world. Later on, the theme of missions never lacked in his academic work.

Voetius never published a systematic mission theology. Important mission views can be found in his published work. Voetius' theology of mission can be found especially in two collections of his work: the Disputationes Theologicae Selectae (1648-1669) and in Politica Ecclesiastica (1663-1676). The first of these two includes discussions on topics such as atheism, Judaism, Mohammedanism, Gentiles, the vocation of the nations, church planting and the examination of true religion. In the latter, in keeping with its primary concern, Voetius treats missions as a division of church polity. He not only sketched the outlines of a solid theology of missions, but he was also the first who seriously attempted to give missiology a legitimate scientific place in the whole of theology (Van Andel 1912:19). As a Reformed Dutch theologian, he was the first to put on paper in a comprehensive, contextual and comparative Protestant way, his ideas about mission. At the newly established Utrecht University where he taught for 42 years (1634-1676) as professor of Semitic languages and theology, he was exposed to mission issues in a direct way. His scholastic and theological agenda was determined by his emphasis on theologia practica.

In the education of the future pastors who also could be called to go to the various Dutch colonies abroad, Voetius saw the necessity to give an explanation on the nonChristian religions. When we zoom into Voetius' theological approach, we must keep in mind that writing about his Reformed tradition we particularly think of the Calvinistic branch of this tradition. It means that in biblical hermeneutics, human understanding of the Scriptures is always incomplete and can never grasp the meaning of the 
scriptural words exhaustively. His theology is theology in context that, in accordance with modern standards, made use of the controversy method and the essential hermeneutic point of view applies that one's own current situation of faith necessarily entails a restriction of one's own horizon of understanding. Reformed theologians have always confessed their faith in tempore and in loco. Voetius follows the scholastic method of Thomas of Aquino, but in systematic theological issues, he follows Calvin's doctrine of the predestination and his emphasis on the soli Deo gloria (cf. Graafland 1989:23-26).

As theology professor, he regularly wrote, particularly as a specialist in church order, about the mission enterprise, both from the systematic and practical theological vantage points. In this, he was not narrow-minded, as he freely used mission related research from the Roman Catholics (Verkuyl 1975:38). He was the first Protestant theologian who developed an all-comprehensive Protestant theology of missions (Jongeneel 2015:36). One of Voetius' first openly mission statements was when he compared the Jesuit mission work with that of the Protestants. He saw that the Jesuits took the wind out of the Protestant sails:

De orde der Jezuieten heeft alle andere missionarissen openlijk de loef afgestoken. [...] Wij van onze kant zullen ons moeten benaarstigen om mensen uit te sturen naar Japan (al hebben wij daar nog geen zendingspost) en naar de verschillende delen van Oost-Indië. (Pol 1910:58)

This brief but nonetheless significant work can be considered as his first writing on the subject of missions.

In his Disputationes Theologicae Selectae (Voetius 1648-1669), we see subjects such as de Atheismo, de Judaismo, de Praejudiciis verae Religionis, de Plantatoribus Ecclesiarum, de Gentilismo et Vocatione Gentium and de Muhammedismo. Voetius dealt with all these subjects in an extensive way as expected from a professor, but also dealt with it as a pastor each time he talked about de ejusdem cura (cf. Van Andel 1912:17). After two years in Utrecht, he started lecturing about Judaism (De Judaismo). In 1638, Voetius talked with his students about heathenism.

In 1644, the first part of Exercitia et Bibliotheca Studiosi Theologiae, appeared, and in the second part, printed in 1551, Voetius devoted more than 60 pages on De Apparatu Theologiae Elencticae (elencho: to refute) with attention to heathens, Jews and Mohammedans. A year later, he published a study about planting churches (De Plantatione Ecclesiarum - see Pol 1910) where many biblical quotations sustain his thoughts. When he published Politica Ecclesiastica (1663-1676) in 1655, mission was seen as part of church law. This brings Jongeneel to the conclusion that Voetius, as professor, was a specialist in church law, as this dealt with mission (Jongeneel 2015:77). Van Andel (1912:18) suggests that Voetius, in his treatment of church law, came on the terrain of missiology and therefore his disputation De Plantatione et Plantatoribus Ecclesiarum is part of his Politica Ecclesiastica (1663-1676). The word Plantatoribus was omitted from the cover which shows that Voetius moved the accent from the persons to the act of mission work. With this, he introduced a new chapter, De Missionibus Ecclesiasticis in which the church law system assists a missionary (Van Andel 1912:18). Voetius regarded mission as a responsibility of the church. Gensichen (1971:101) sees a direct connection between the ideology of the corpus christianum of the Middle Ages which shows that Voetius moved the accent from the mission workers to the act of mission work. Voetius refers to Ephesians 3:10 and Romans 11:32 (Van Andel 1912:150) where the present gospel preaching, from the time before Christ until now, finally will be dragged upon the universal eschatological horizon.

\section{Mission theology}

Voetius gave the mission, as object of his theology, different names:

1. The calling of the people without the knowledge of Christ (Vocatio gentium).

2. The planting of the church or churches (Plantatio ecclesiae aut ecclesiarum).

3. And under the influence of Rovenius (1573-1661) - about missions (Missiones) (Van Andel 1912:75).

The last of the three could be lawful church missions and the unlawful papal missions (Missiones Papatus).

Mission work is 'to enter into or going out into the service of the Word of God by the official church' (Van Andel 1912:75). Mission work is more or less everything what is implied by the phrase to send. Bosch argues that Calvin's theological point of departure - the reign of Christ - gave rise to the idea of mission as 'extending the reign of Christ' by inward spiritual renewal of individuals and by transforming the face of the earth through filling it with 'the knowledge of the Lord'. He says that in the early 17th century, Voetius is of 'crucial importance' to intertwine these two dimensions of Calvin's mission idea 'in a creative tension' (Bosch 2001 [1991]:256).

Voetius' mission theology is formally scholastic and indebted to Thomas Aquino, but the guide to his systematictheological approach is Calvin's dogma of predestination and the latter's emphasis on the soli Deo gloria. Fundamentally, for Voetius, mission work is founded in the sovereign will of God and in his election of Christians and churches to do his holy will. Only the true church, according to the will of God, should do mission work. Those outside the 'true church' are, firstly, the infidels; secondly, the heretic; and thirdly, the schismatic. For Voetius, the infidels were the heathen, the Jews and the Muslims. In dealing with the infidels, one should first unmask their religion as false and then start with gospel preaching. This doctrinal approach distinguished the work of Voetius' students who went overseas (Jongeneel 2015:36). Conversion and the planting of a church are the two main purposes of mission work next to the highest goal of mission: the glorification of God. The importance of Christian obedience is not to be ignored, but 'the deepest root of missionary calling is gratitude and wonder at the manifestation of God's love' (Kritzinger, Meiring \& Saayman 1994:1; Verkuyl 1975:38). 


\section{Biblical foundation}

'To Voetius' credit is that he honestly sought the principles of missions within the Scriptures and allowed his every effect to be guided by their teaching' (Bavinck 1960:XIV). However, Voetius did not deal with it in a very extensive way as we see two ages later when missiologists such as Gustav Warneck (1834-1910) in his famous Evangelische Missionslehre (Warneck 2011 [1892]) were confronted with more practical problems and elaborated a further biblical foundation. God is and he alone is, according to Voetius the Sender, the auctor primaries who inspires his church and those who are definitely going out to proclaim the gospel. Planting and planters (1 Cor 3:7) as well as the metaphors of the church as God's field (1 Cor 3, 9), a (pleasure) garden (Song of Songs 4, 12, 13) and a vineyard (Is 5) are the Scriptural notions Voetius used for his missiology. Believers are described as fruit bearing trees (Ps 1), branches of a tree (Jn 15) and branches of an olive tree (Rm 11). Planting is bringing together the believers and the first meeting of non-believers who are now converted to Christianity into a church body or a first constitution of a church or churches (Van Andel 1912:18). Those who hear the Word of God, the auditores, will receive baptism and teaching (the catechumeni), and after baptism they will become members of the church (membra ecclesiae). Voetius blames the Roman Catholics that their first aim is not the spreading of the gospel, but the growth of the papal hegemony. He accused the papal missionaries to have an easy life. Om een lecker en makkelijk leventje te hebben en het brengen van schatten in de schatkist (Pol 1910:23).

Quis sint mittentes? Voetius stresses that the sending bodies should be the churches and the ecclesiastical representatives. Mittentes ordinario sunt quelibet ecclesiae seu ecclesiastica collegia (Pol 1910:39) and that those who send, will act according the rule of the churches and be church bodies. Mittentes ordinario sunt quelibet ecclesiae seu ecclesiastica collegia (Pol 1910:39, 322). The sending will be done mostly in consistorial, classical and synodical connexion. Kings and governments do not have the authority to send the 'planters'. Therefore, Voetius pleaded for ecclesiastical mission. Mission and vocation go hand in hand. Proof of this is, for Voetius, Romans 10:15: 'How will they preach without being sent? Where do those go who are sent?' In general, for Voetius, they go to all who are drifted apart from the true church. He cites 2 Chronicles 30:6 where King Hizkia calls back the people to God. The purpose of mission work is the conversion of the heathen, the gathering of those who are scattered, the reformation of doctrine and to enforce church disciples. That, which was a hot issue for Voetius in the young Reformed church in the Netherlands, he also desired for the church on the mission field: a holy conduct of the new believers where God's will shall be glorified in their lives.

Voetius also had an eye to heal church schisms or separated churches, assist poor churches and to remove difficulties which hinder the beginning of new churches. Those who will be going to the mission field need to know the Scriptures and have a basic knowledge of philosophy. Knowledge of the
Bible is necessary to 'remove the weeds' and to sow the good seed, and the philosophy is to know how the heathen are thinking. Acts 17 gives Voetius the tools for this statement. The underlying theological fundament for mission work is the will of God as seen in his eternal decision and in his promises for the future and the mission task, as this is in force in the actual mission situation. For Voetius, God's vocation is universal. The vocatione externa, as is done on the mission field, has to result in the vocatio internal, which leads to conversio et salus. The conversion itself is defined as a growing into fellowship with Christ (conversio salutaris et per fidem communion Christi) (Van Andel 1912:62). The ultimate purpose of all missionary work, de causa finalis ultima et suprema is focused on the gloria et manifestatio gratiae divinae (Jongeneel 2015:127; Van Andel 1912:143). Ultimo, in the glorious meeting in heaven of the elect, shines the glory of God (In collectio et salus electorum shines the gloria et manifestatio gratiae divinae). As Jongeneel (1991) says:

[Voetius'] Protestant theology of mission properly subordinated all concrete missionary activity to the praise, honour and adoration of God and precisely for this reason was able to develop a broad vision which makes possible a world-wide, non-coercive mission to convert people from every race and plant the church of Christ everywhere. (p. 79)

\section{A triplicate aim}

We saw that, for Voetius, the first goal of mission is the conversion of the heathen (conversio gentilium); the second, the planting of churches (plantatio ecclesiae); and the highest goal is the glory of God (gloria et manifestatio gratiae divinae) (Bavinck 1954:157; Verkuyl 1978:21, 64). According to Kritzinger et al. (1994:2), the glory and manifestation of God's grace should be recognised as our deepest missionary commitment and our highest missionary goal. It is very important to realise that the involvement of individuals, churches and mission organizations in God's mission is a response to the manifestation of God's love. Since the start of the modern Protestant missionary movement with William Carey (1761-1834) as the founder of the modern missionary movement, the most prominent motivating factor in mission is considered to be obedient to the so-called Great Commission (Mt 28:16-20). Seen from the actual reality of God's decision, Voetius believed that Christ's merit is limited to the elect. Yet, we see in Voetius the breadth of the Reformed orthodoxy. He always invited his opponents for a talk. To do effective mission work, he urged to know the other. In De Muhammedismo he pleads, next to Scripture study and a holy life, for academic tools to know the philosophy and the knowledge of the Arabic language, a good library and to qualify oneself into the skills of a debate. Fitted with these skills, one can enter in debate with Muslims to say frank and straightforward of the Koran that it is not the Word of God (cf. Van Asselt 1995a:229-251).

Voetius saw and studied the 'theory' of mission not as a discipline on its own. He developed his missiology as the result of his own thinking about mission. Yet, in his lectures, he uses different names for mission work. In his oldest mission 
studies of 1638, De Gentilismo et vocatione Gentium, he uses the name Vocatio Gentium. In 1652, he speaks of Plantatio Ecclesiae aut Ecclesiae. The name Missiones currently became Zendingsleer in the Dutch language and is used by the mission specialist, Warneck (2011 [(1892]), as Missionslehre.

The church's clear trumpet should sound throughout every sphere of society. An intense focus on faith and piety ought to magnify and not limit the church's role in society. Due to the world-encompassing lordship of Christ, Voetius had great hope for the gospel's success in the Netherlands and among the nations. To assist the church in carrying out its mission mandate, he wrote De Plantatione Ecclesiarum (see Pol 1910) and with this study, he hoped to bind the mission call on the students to serve in foreign countries. (Van 't Spijker 1986:75-82). As seen above, Voetius did not want the government to interfere in church affairs, but emphasised that all ecclesiastical authority must be subservient to Christ. The litmus test of a church is whether Christ would be able to exercise his lordship through his Word. Voetius held broad views of Christ's lordship over the church. The 'fencing off' of the church's authority from the civil government, ought not to 'fence in' the church, however.

\section{'Risen to prominence'}

We considered Voetius in the framework and against the background of his time. He wrote and lectured in a scholastic way and lived and preached in a pietistic way of life. However, his mission concept remained rather theoretic. How far he would have come, exclaims Van de Linde (1976b:215), if his mission theory would have been poured from theory into, for him so important, the 'sause der practijk'? However, his influence lasted long. Although not a creator of a new theology, he was a competent systematiser who influenced thousands. He was instrumental in training hundreds of ministers who followed his footsteps. Voetius' scholastic methodology merged with practical piety was dominant in the 17th-century Reformed theology and formed an important stream in the Dutch Protestant theology of the next ages (Van Asselt 1995b:3). 'A giant among trail blazers', Gentman said at his funeral (Beeke 1999:35). Many students from the Academia Voetiana, as the Utrecht University was called at that time, continued to spread his theology among the Reformed theologians. For many students his theology became a program. With their powerful combination of orthodox doctrine and vital piety, the Voetians set a stamp on the Dutch theology for many years. Even in England, he was seen as one of the most important theologians of the continent. His academic writings disseminated his thoughts throughout the Netherlands and beyond. Pastors sent their sons to Utrecht to study at Voetius' university (Sprunger 1982:359). Voetian theology lives on today in the Dutch Reformed experiential tradition in the Netherlands, North America and Canada. The Redelijke Godsdienst, written by Wilhelmus à Brakel (1635-1711), a Voetian theologian, was translated in 1995 as The Christian's Reasonable Service (à Brakel 1992-1995). This work did much to keep Voetius' theology alive. Bosch (2001 [1991]) formulates that Voetius' threefold goal of mission is 'still unparalleled' and, for Voetius, the foundation of mission 'is flowing from the very heart of God'. 'Since the middle of the twentieth century, in particular, it has once risen to prominence' (Bosch 2001 [1991]:256, 257, 286).

\section{J.H. Bavinck}

In the Netherlands, the influence of Voetius' mission theory and practice was great in the churches of the Doleantie. Abraham Kuyper (1837-1920), the founder of the Free University in Amsterdam, orientated himself for his theology on Voetius (Van de Linde 1976b:275). He used Acts 13 to explain Voetius' principles and characteristics of missiology. He also used Voetius' division:

1. The ultimate goal.

2. Who sends.

3. Whom to send.

4. To whom men are sent.

5. How to do mission work.

The Synod in Middelburg (1896) did not vote for the nondenominational mission system of William Carey, but for a church related mission. Within the Gereformeerde Kerken, a biblical view of mission was based on Voetius' thoughts (Jongeneel 1991:74). In the 20th century the missiology professors at the Vrije Universiteit, Amsterdam, J.H. Bavinck and J. Verkuyl, saw Voetius' mission concept as their starting point to develop their own mission ideas. Bavinck (1954:7, 21) spoke with respect of the first Reformed Dutch theologian and missiologist, Voetius. He emphasised in his Science of Missions the cohesion between the three aims of Voetius and adds: 'It is striking that Voetius is not concerned with the biblical foundation of missions. This question was not so strong an issue in his day' (Bavinck 1960:6):

1. Bavinck was influenced by Voetius in his theocentricity. Mission is primarily God's work.

2. He (Bavinck 1948:32ff.) also followed his ecclesiocentric conception of mission. Mission work has not to be done by societies, but belongs exclusively to the church.

3. Bavinck (1960:155-159) adopted the threefold aim of missions: the conversion of unbelievers (conversio gentilium), the establishment of the church (plantatio ecclesiae) and the glorification of God (gloria gratiae divinae)

4. Bavinck (cf. his 'Kerygmatic approach' - 1960:121-152) made a distinction between the ecclesiastical missionary work of ordained ministers of the Word and the ancillary services of other mission personnel, for example teachers, medical workers, et cetera.

5. Under the influence of Kuyper, Bavinck (1960:221-272) gave Voetius' theologia elenctica a prominent place in his handbook on missiology.

In 1951, the Protestant Church in the Netherlands formulated the mission paragraph of the church in Voetius' ecclesiastical vision. The Reformed Mission League (Gereformeerde Zendingsbond - GZB) in the Netherlands, founded in 1901, accepted the Reformed theology of the Reformation as normative (Van den End 1985:4) and for 'purpose and method' followed the Reformed principles as formulated by Voetius 
(cf. Van den End 1985:4, 73). Piety combined with intellect can also be seen in the mission drive of many Reformed church dominations. This intelligent piety gives connection and is able to build bridges within different cultures, theologies and churches.

\section{Conclusion}

Abiding in Voetius' missiology is that, in his theology, everyone - the workers and the missionary activities - are all subordinated to the honour, praise, glorification and adoration of God. Independent of ideologies and institutions, the church is called in obedience to God. For his time, Voetius was modern and broke through barriers, giving the Bible all the credit when he dealt with mission issues. Since the Second World War, missiologists talk about missio Dei, while Voetius already saw mission work in the first instance as God's work and, secondary to this, the work of his people. Unfortunately, Voetius has been overlooked for a long time in missionary circles and, in our present time with so much human activities, mission work needs to restrain itself and realise that all the work is provision and that the adoration of God who came in love to save the world is the ultimate mission goal.

Many reports nowadays show that the corpus christianum era is passé. Voetius' mission proposals are dated - he stood at the beginning of the colonial period, while contemporary missiology is confronted with what the past has handed over to us. We live in a new challenging time (cf. CBS-report 2018) and have to redefine the work of the church, whereby Voetius' accent upon God has to take the initiative and his glory to be the ultimate goal. Inspired by Voetius, God's sovereignty over everything and the manifestation of his glory is also for us the motive for mission work, for the world and its fullness belongs to him.

\section{Acknowledgement \\ Competing interest}

The author declares that no competing interest exists.

\section{Author contributions}

I declare that I am the sole author of this research article.

\section{Funding}

This research received no specific grant from any funding agency in the public, commercial, or not-for-profit sectors.

\section{Data availability statement}

Data sharing is not applicable to this article as no new data were created or analysed in this study.

\section{Disclaimer}

The views and opinions expressed in this article are those of the author and do not necessarily reflect the official policy or position of any affiliated agency of the author.

\section{Ethical consideration}

This article followed all ethical standards for carrying out research without direct contact with human or animal subjects.

\section{References}

à Brakel, W., 1992-1995, The Christian's reasonable service, ed. J. Beeke, transl. B. Elshout, 4 vols., Soli Deo Gloria, Morgan, Pa.

Bakhuizen van den Brink, J.N. (ed.), 1960, Documenta Reformatoria: Teksten uit de geschiedenis van Kerk en Theologie in de Nederlanden sedert de Hervorming, dl. 1, Kok, Kampen.

Bavinck, J.H., 1948, Zending in een wereld in nood, 4e druk, Zomer \& Keuning's Uitgeversmij, Wageningen.

Bavinck, J.H., 1954, Inleiding in de Zendingswetenschap, Kok, Kampen.

Bavinck, J.H., 1960, An introduction to the science of missions, Presbyterian \& Reformed Publishing Co., Phillipsburg, NJ.

Beeke, J.R., 1999, Gisbertus Voetius toward a reformed marriage of knowledge and piety, Reformation Heritage Books, Grand Rapids, MI.

Biografisch lexicon voor de geschiedenis van het Nederlandse Protestantisme (BLGNP), 1978-2006, DI. I-VI, Kok, Kampen,

Bosch, D., 2001 [1991], Transforming mission, Paradigm shifts in theology of mission, Orbis Books, Maryknoll, NY.

Calvijn, J., n.d., Institutie, of onderwijzing in de christelijke godsdienst, ed. A. Sizoo, W.D. Meinema, Delft.

CBS-report, 2018, viewed 20 October 2018, from https://www.cbs.nl/nl-nl/nieuws/ 2018/43/meer-dan-de-helft-nederlanders-niet-religieus.

Dankbaar, W.F., 1978, 'Het apostolaat bij Calvijn', in W. Balke (ed.), Hervormers en Humanisten, pp. 185-199, Amsterdam, Ton Bolland.

Erasmus, D., 1535, Ecclesiastes sive de ratione concionandi, Froben, Basel.

Galm, M.P., 1915, Das Erwachen des Missionsgedankens im Protestantismus der Niederlande, Missionsverlag St. Ottilien, St. Ottilien.

Gensichen, H.W., 1971, Glaube für die Welt: Theologische Aspekte der Mission Gütersloher Verlagshaus Gerd Mohn, Gütersloh.

Graafland, C., 1989, 'Voetius als gereformeerd theoloog', in J. van Oort (ed.), De onbekende Voetius: Voordrachten wetenschappelijk symposium Utrecht 3 maart 1989, pp. 12-31, Kok, Kampen.

Hofmeyr, J.W. 1989, Die Nederlandse nadere reformasie en sy invloed op twee kontinente, Universiteit van Suid-Afrika, Pretoria.

Jongeneel, J.A.B., 1991, 'The missiology of Gisbertus Voetius: the first comprehensive Protestant theology of missions', Calvin Theological Journal 26(1), 47-79, Grand Rapids, Calvin Theological College.

Jongeneel, J.A.B., 2015, Nederlandse zendingsgeschiedenis: Ontmoeting van protestantse christenen met andere godsdiensten en geloven (1601-1917), Boekencentrum Academic, Zoetermeer.

Joosse, L.J., 1992, 'Scoone Dingen Sijn Swaere Dingen': Een onderzoek naar de motieven en activiteiten in de Nederlanden tot verbreiding van de gereformeerde religie gedurende de eerste helft van de zeventiende eeuw, Groen \& Zn, Leiden.

Kaajan, H., 1914, De pro-acta der Dordtsche synode in 1618, T. de Vries, Rotterdam.

Klooster, F.H., 1972, 'Missions - The Heidelberg Catechism and Calvin', Calvin Theological Journal 7(2), 181-208, Grand Rapids, Calvin Theological Seminary.

Kritzinger, J.J., Meiring, P.G.J. \& Saayman, W.A., 1994, On being witnesses, Orion, Johannesburg.

Krüger, J.J.F., 2007, 'The reformed confessions: Embarrassment or blessing to a missionary church?', In die Skriflig 41(4), 549-570.

Kuyper, H.H., 1899, De Post-Acta of Na-handelingen van de Nationale Synode van Dordrecht in 1618 en 1619 Gehouden, Hoveker \& Wormser, Amsterdam.

Mackichan, D., 1927, The missionary ideal in the Scottish Churches, Hodder \& Stoughton, London.

Neill, S., 1982, A history of Christian missions, Penguin Books, Hammondsworth.

Niemeijer, H.E., 1996, 'Calvinisme en koloniale stadscultuur Batavia', in Y. Soleiman (ed.), The Dutch reformed church in late eighteenth century Java: An eastern adventure, pp. 8-32, Vrije Universiteit, Amsterdam.

Pol, D. (ed.), 1910, G. Voetius, Tractaat over de planting en de planters van kerken, vert. G. Voetius' De Plantatione Ecclesiarum, Groningen, Delpher.

Scholl, H., 1968, De Dienst des Gebetes nach Johannes Calvin, Stuttgart, Zwingli Verlag, Zürich.

Sprunger, K., 1982, Dutch Puritanism, Brill, Leiden.

Van Andel, H.A., 1912, De Zendingsleer van Gisbertus Voetius, Kok, Kampen.

Van Asselt, W.J., 1995a, 'De Islam in de beoordeling van Johannes Coccejus en Gisbertus Voetius', Kerk en Theologie 46, 229-251, Boekencentrum, Zoetermeer.

Van Asselt, W.J., 1995b, 'Herwaardering van de gereformeerde scholastiek', Kerktijd, Contactblad voor de Vereniging Nederlandse Kerkgeschiedenis 7, 1-12.

Van Asselt, W.J., 2007, Voetius, De Groot \& Goudriaan, Kampen. 
Van de Linde, S., 1976a, 'Het opkomen en de eerste uitwerking van de zendingsgedachte binnen het Nederlands Gereformeerde Protestantisme', in J.W. Arendshorst (ed.) Opgang en voortgang der Reformatie, pp. 201-206, Ton Bolland, Amsterdam.

Van de Linde, S., 1976b, Opgang en Voortgang der Reformatie: Een keuze uit de nagelaten artikelen van Prof. Dr. S. van der Linde, ed. J.W. Arendshorst, Ton Bolland, Amsterdam.

Van den Berg, J. (ed.), 1978, Pietismus und Reveil: Der Pietismus in den Niederlanden und seine internationalen Beziehungen, Brill, Leiden.

Van den Bosch, J.W., (1932-1933), 'Martinus Bucer en de zending', Gereformeerd Theologisch Tijdschrift 33, 492-514 en 544-568.

Van den End, Th., 1985, De Gereformeerde Zendingsbond 1901-1961, Nederland Tanah Toraja: Een bronnenpublicatie, Driebergen, Raad voor de Zending der NHK, Gereformeerderde Kerken in Nederland, Gereformeerde Zendingsbond (GZB), Driebergen

Van Oosterzee, J.J., 1883, 'Gysbertus Voetius', in J.J. Herzog (ed.), Schaff-Herzog Encyclopedia of Religious Knowledge, vol. 3, p. 2464, Funk \& Wagnalls, New York.

Van 't Spijker, W., 1986, 'Gisbertus Voetius (1589-1676)', in T. Brienen \& K. Exalto (eds.), De Nadere Reformatie: beschrijving van haar voornaamste vertegenwoordigers, pp. 49-84, Boekencentrum, Den Haag.

Verkuyl, J., 1975, Inleiding in de Nieuwere Zendingswetenschap, Kok, Kampen

Verkuyl, J., 1978, De onvoltooide taak der wereldzending, Kok, Kampen.
Voetius, G., 1641, Dry Disputatien, d'Eerste Van de Fundamentele Articulen ende Dwalinghen - d'Andere Twee Van de Nootsakelijckheyt ende Nutticheyt van het Leer-stuck van de H. Dry-Eenicheyt, E.W. Snellaert, Utrecht.

Voetius, G., 1651 [1644], Exercitia et Bibliotheca Studiosi Theologiae, editio secunda, Ant. Smytegelt, Ultrajecti. (B.d.V.U.A.).

Voetius, G., 1659, Catechisatie, Dat is, Een grondige ende eenvoudige Onderwijsinghe over de Leere des Christelicken Catechismi; Bestaande in Vragen en Antwoorden, 3rd edn., C. Poudroyen, Amsterdam.

Voetius, G., 1664, Te Asketika sive Exercitia pietatis, Vink, Gorinchemi.

Voetius, G., 1648-1669, Disputationes Theologicae Selectae, 5 tomi., Ant. Smytegelt, Ultrajecti.

Voetius, G., 1663-1676, Politica Ecclesiastica, 3 partes, 4 tomi., Johannes à Waesberge, Amstelodami.

Warneck, G., 1900, Abriss einer Geschichte der protestantischen Missionen von der Reformation bis auf die Gegenwart: Ein Beitrag zur neueren Kirchengeschichte, 6th Aufl., Warneck Verlag, Berlin.

Warneck, G., 2011 [1892], Evangelische Missionslehre, Nabu Press, Charleston, SC.

Welzig, W. (ed.), 1968, 'Enchiridion', in E. van Rotterdam (ed.), Ausgewählte Schriften, Bd. 1, pp. 55-375, Wissenschaftliche Buchgesellschaft, Darmstadt.

Wiersinga, H.A., 1959, Geschiedenis van de Zending, Kok, Kampen. 